\title{
Article \\ The Influence of New Agricultural Business Entities on the Economic Welfare of Farmer's Families
}

\author{
Lingjuan Cheng ${ }^{1}$, Wei Zou ${ }^{1, *}$ and Kaifeng Duan ${ }^{2, *(D)}$ \\ 1 College of Public Administration, Nanjing Agricultural University, Nanjing 210095, China; \\ 2019209017@njau.edu.cn \\ 2 School of Economics and Management, Tongii University, Shanghai 200092, China \\ * Correspondence: ZWnjau2021@163.com (W.Z.); kefee920729@tongji.edu.cn (K.D.)
}

check for updates

Citation: Cheng, L.; Zou, W.; Duan, K. The Influence of New Agricultural Business Entities on the Economic Welfare of Farmer's Families. Agriculture 2021, 11, 880. https://doi.org/10.3390/ agriculture11090880

Academic Editor: Sanzidur Rahman

Received: 3 August 2021

Accepted: 12 September 2021

Published: 14 September 2021

Publisher's Note: MDPI stays neutral with regard to jurisdictional claims in published maps and institutional affiliations.

Copyright: (c) 2021 by the authors. Licensee MDPI, Basel, Switzerland. This article is an open access article distributed under the terms and conditions of the Creative Commons Attribution (CC BY) license (https:/ / creativecommons.org/licenses/by/ $4.0 /)$.

\begin{abstract}
Promoting the coordinated development of new agricultural business entities and small farmers is an important way to realize rural revitalization. It is undoubtedly of great significance to clarify the impact and its mechanism of new agricultural business entities on the economic welfare of farmers' families. Based on the 2015 China Household Finance Survey (CHFS) data, this paper builds a theoretical analytical framework of "new agricultural business entities-non-agricultural employment and agricultural output—economic welfare of farmers' family". From the intermediary perspective of the non-agricultural employment and agricultural output, it empirically tests the impact of new agricultural business entities on the economic welfare of farmers' families by combining the analysis methods of the benchmark regression and intermediary effect. The research shows that: (1) New agricultural business entities promote the improvement of the economic welfare of farmers families. The specific manifestation is that the existence of new agricultural business entities can not only increase the per capita annual income of farmers' families, but also promote the per capita consumption expenditure of farmers' families in the village. (2) Non-agricultural employment and agricultural output have a significant mediating effect in the impact of new agricultural business entities on the economic welfare of farmers' families. (3) In addition to key variables, variables such as education, political status, and family status are also key factors affecting the economic welfare of farmers' families. Finally, this paper puts forward some policy recommendations such as cultivating high-quality new agricultural business entities, strengthening farmers' technical training, and optimizing rural residents' policies.
\end{abstract}

Keywords: new agricultural business entities; non-agricultural employment; agricultural output; economic welfare; farmers' families

\section{Introduction}

Since the founding of the People's Republic of China, China's rural economic development has achieved a historic leap, the agricultural and rural landscape has undergone earth-shaking changes. However, the lag of agricultural development is still an important factor restricting China's social and economic development. Under the background of land fragmentation, farm aging, non-agriculturalization of agricultural production factors, part-time farming, and coexistence of high-risk agricultural production and agricultural cost, "who will farm the land" is a major problem that needs to be solved at present. Therefore, the state has issued a series of policies and measures to cultivate and develop new agricultural business entities. With the continuous emergence of new agricultural business entities, it has become the backbone to promote the revitalization of rural industries. Will the new agricultural business entities in the countryside improve the economic welfare of local farmers' families? As landowners, whether farmers can enjoy the dividends brought by the new agricultural business entities directly affects farmers' support for this policy. Therefore, it is particularly important to deeply analyze the impact of new agricultural business entities on the economic welfare of farmers' families. 
Before 2012, the concept of "new agricultural business entities" has not generally been recognized and standardized. Since 2012, the term "new agricultural business entities" has appeared widely in local and central official documents. For example, at the end of 2012, the Central Rural Work Conference formally proposed to cultivate and develop new agricultural business entities; the No. 1 document of the CPC Central Committee in 2013 pointed out that "innovation of agricultural production and operation organization is the core and foundation for promoting the construction of modern agriculture. We should respect and guarantee the dominant position of farmers in production and operation, cultivate and strengthen new agricultural production and operation organizations, and fully stimulate the potential of rural production factors." Since then, related research has begun to increase, and the definition of the concepts has gradually been enriched. All circles agree that the new agricultural business entities should include family farms, farmers professional cooperatives, agricultural leading enterprises, etc. The new agricultural business entities which made commercial production as the main goal of agricultural operation organizations, compared with a small farmer, have a relativity large area of cultivated land, a higher scientific and technological level and management ability, etc. With strong support from national policies, as of 2018, there were more than 3 million new agricultural business entities, including nearly 600,000 family farms, 2.173 million legally registered farmer cooperatives, and 370,000 social service organizations engaged in agricultural production trusteeship. The new agricultural business entities are the "leader" of China's agricultural modernization. It can be said that the new agricultural business entities have become a new entity supported by rural industrial policies, a new carrier of rural moderate scale operation, and a new bright spot for farmers' income growth. Accelerating the development of new agricultural business entities is an inevitable requirement for the construction of agricultural modernization.

At present, the academic research on new agricultural business entities mainly focuses on the following four aspects. First, taking the new agricultural business entities themselves as the research objects, the research is mainly conducted from the perspectives of economic performance [1], development methods and functions [2,3], financing demand and financing dilemma [4-6], and policy selection and optimization [7]. Second, the influence of the new agricultural business entities on land transfer. The new agricultural business entities expand the scale of farmland management, promote the development of the local land market, increase the land rent [8], and raise the property income of farmers through land transfer [9]. Third, the driving effect of new agricultural business entities on the farmers employment. Research shows that the new agricultural business entities provide a certain number of jobs for farmers and solve a part of the surplus labor force problem in rural areas $[3,10]$ through expanding the scale of farmland management and the three industries' integration. Fourth, the impact of new agricultural business entities on farmers' income. The new agricultural business entities further reduce farmers' transaction costs [11] and increase farmers' income by providing productive services [12-14] and establishing an interest-linking model with small farmers [15-19], but they are mainly based on qualitative or case analyses.

In the present study, it was found that by reviewing and sorting the previous related literature, rich research results had been yielded related to the effects of the new agricultural business entities on farmers. However, there were still found to be shortcomings. First, the existing research result had mainly taken the impact of new agricultural business entities on the farmers' income, and ignored the mechanism and effect of new agricultural business entities on the economic welfare of farmers' families. Second, the existing studies mainly focused on qualitative analysis and case analysis, and few explored the impact of new agricultural business entities on small farmers from the quantitative perspective. Third, the research area was relatively small and it was difficult to reflect the basic situation of the whole country. Therefore, based on the aforementioned shortcomings, the main contributions of the present study are as follows: (1) this study builds a theoretical analytical framework of "new agricultural business entities-non-agricultural employment 
and agricultural output-economic welfare of farmers' families" under the guidance of information economics theory; (2) the 2015 China Household Finance Survey (CHFS) data were utilized to examine the mediation effects of non-agricultural employment and agricultural output between the new agricultural business entities and the economic welfare of farmers' families from the national level. It is of practical significance to improve the relevant policies and systems of the new agricultural business entities and to promote the coordinated development of the new agricultural business entities and small farmers.

\section{Theoretical Analysis and Research Hypotheses}

This study mainly focuses on addressing two research questions: First, what is the relationship between the new agricultural business entities and the economic welfare of farmers' families? Second, if there is a relationship, what is the impact mechanism of the new agricultural business entities on the economic welfare of farmers' families? In this way, it can be judged whether the current new agricultural business entities really improve the economic welfare of farmers' families.

\subsection{The Impact of New Agricultural Business Entities on the Economic Welfare of Farmers' Families}

New agricultural business entities can improve the economic welfare of farmers' families by alleviating the "lock-in effect" and improving the market-driven effect. First, alleviating the "lock-in effect". As a social security function of farmers, cultivated land has a "lock-in effect" on rural labor force. However, new agricultural business entities into the countryside accelerate the development of the local land transfer market, which weakens the "lock-in effect" of cultivated land on farmers to a certain extent. As a result, farmers with advantages of non-agricultural employment will be released from agriculture to obtain higher returns for non-agricultural employment and further improve the economic welfare of farmers' families. Second, improving the market-driven effect. The new agricultural business entities have scale advantages in terms of factor purchases and agricultural product sales, such as the purchase of pesticides, fertilizers, and agricultural machinery services at low prices, or selling agricultural products at high prices. The surrounding farmers participate in the purchase and sales of new agricultural business entities by the "free rider" method, which is beneficial to reduce the input cost and transaction cost of agricultural production factors, alleviate the contradiction between small farmers and the big market, increase farmers' agricultural income, and improve the economic welfare level of farmers' families.

H1. The new agricultural business entities are conducive to enhancing the impact of the economic welfare of farmers' families.

\subsection{The Impact of New Agricultural Business Entities and the Non-Agricultural Employment on the Economic Welfare of Farmers' Families}

The new agricultural business entities affect the non-agricultural income of farmers' families by promoting non-agricultural employment behaviors of farmers, thereby improving the economic welfare of farmers' families. First, the three industries' integration effect. The new agricultural business entities will promote the development of other local related industries and provide more employment opportunities for farmers. At the same time, through the extension of the industrial chain, the new agricultural business entities will also increase farmers' non-agricultural employment opportunities, thereby increasing the economic welfare of farmers' families. Second, the effect of resources optimization allocation. The new agricultural business entities enter the countryside to accelerate the development of the local farmland transfer market. As a "rational economic man", the main purpose of farmers is to maximize economic benefits, so that farmers with non-agricultural advantages can re-optimize the allocation of family resources and transfer agricultural labor to the non-agricultural employment sector, thereby obtaining more non-agricultural income, and improving the economic welfare of farmers' families. 
H2. The new agricultural business entities influence the economic welfare of farmers' families by influencing non-agricultural employment behavior. Non-agricultural employment has a mediating effect in the effect of the new agricultural business entities on the economic welfare of farmers' families.

\subsection{The Impact of New Agricultural Business Entities and Agricultural Output on the Economic} Welfare of Farmers Families

The new agricultural business entities improve the economic welfare of farmers' families by agricultural output. First, technology spillover effects. The new agricultural business entities have advantages in many aspects such as resources, technology, and capabilities. The introduction of advanced technology and management and business models into rural areas can optimize the structure of production factors in rural areas, which is conducive to improving agricultural technical efficiency, increasing agricultural output, and thereby improving the economic welfare of farmers' families. Second, the knowledge spillover effect. Small farmers communicate with new agricultural business entities to improve their knowledge and skills, raise agricultural output and income, and increase the economic welfare of farmers' families. Third, the demonstration effect. The intensive, specialized, and large-scale operations of the new agricultural business entities have a demonstration effect on small farmers, which makes the farmers with agricultural management advantages expand the scale of farmland management, increase the agricultural output, and improve the economic welfare of farmers' families.

H3. The new agricultural business entities influence the economic welfare of farmers' families through agricultural output, and the agricultural output has a mediating effect in the effect of the new agricultural business entities on the economic welfare of farmers' families.

New agricultural business entities may indirectly affect the economic welfare of farmers' families through the two paths of non-agricultural employment and agricultural output, i.e., "new agricultural business entities—non-agricultural employment and agricultural output-family economic welfare" (as shown in Figure 1).

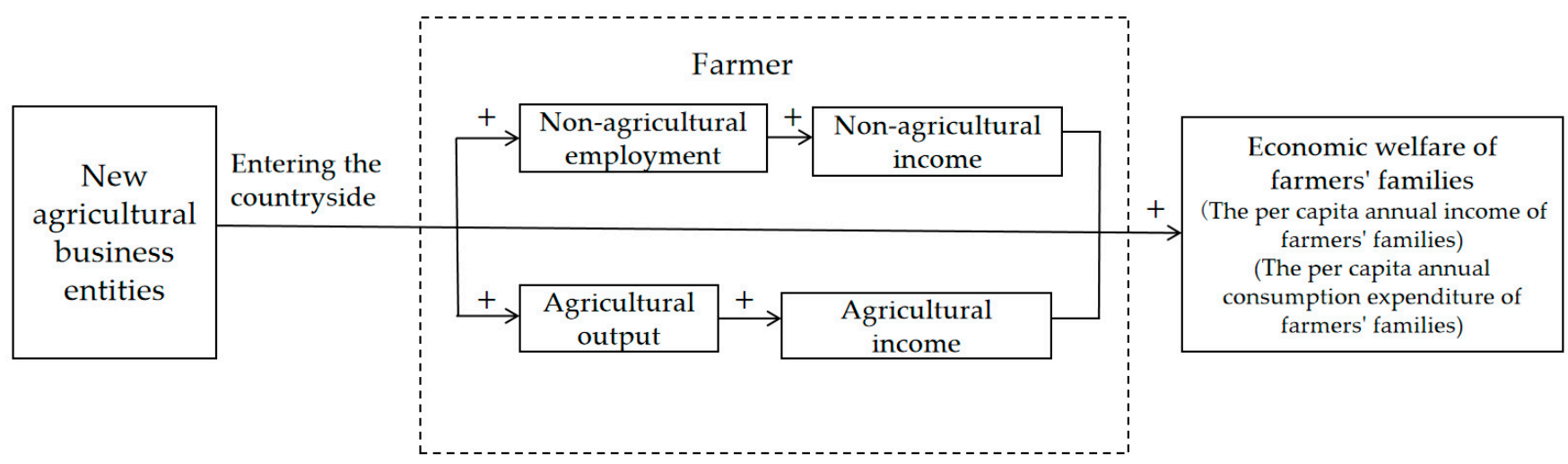

Figure 1. A theoretical framework of the influence of new agricultural business entities on the economic welfare of farmers' families.

\section{Materials and Methods}

\subsection{Sources of Data}

This paper uses data from the 2015 China Household Finance Survey for analysis. The data is a nationwide sample survey conducted by the Survey and Research Center for China Household Finance. The samples are distributed in 29 provinces (autonomous regions and municipalities), 1396 village committees in 351 counties, and the total sample size is 37,289 households. The data coverage is wide, the sample size is large, and the data of this paper have representativeness which guarantees the accuracy of the research conclusion to 
a certain extent. The contents of the questionnaire include the new agricultural business entities, family characteristics, agricultural production, operation characteristics, etc., which provide the basis for this study. For research needs, the household data is connected with the household head data by using the household head ID as the identification code, and the data is cleaned. Finally, only small farmers whose cultivated land scale is less than $50 \mathrm{mu}$ are retained in this paper, and 7764 valid questionnaires were obtained.

\subsection{Variables}

Core independent variable: This study opted to use "whether the new agricultural business entities exist in the village" to represent the core independent variable. Combining the question "To which of the following operating types does your family business belong?" in the CHFS questionnaire, if the answer is family farms, agricultural cooperatives, agricultural enterprises, or large planting households, it indicates that the new agricultural business entities exist in the village, then the value is 1 . Otherwise, it is 0 (as shown in Table 1).

Table 1. Variable definition and summary statistics.

\begin{tabular}{|c|c|c|c|c|}
\hline & Variables & Definition & Mean & S.D. \\
\hline \multirow{2}{*}{ Dependent variable } & \multirow{2}{*}{$\begin{array}{l}\text { Economic welfare of } \\
\text { farmers' family }\end{array}$} & $\begin{array}{l}\text { The per capita annual income of farmers' families } \\
\text { (CNY) }\end{array}$ & $10,797.469$ & $15,952.139$ \\
\hline & & $\begin{array}{l}\text { The per capita annual consumption expenditure } \\
\text { of farmers' families (CNY) }\end{array}$ & 6674.230 & 7142.191 \\
\hline $\begin{array}{l}\text { Core independent } \\
\text { variable }\end{array}$ & $\begin{array}{l}\text { New agricultural } \\
\text { business entities }\end{array}$ & $\begin{array}{l}\text { Whether the new agricultural business entities } \\
\text { exist in the village? exist }=1 \text {; otherwise }=0\end{array}$ & 0.701 & 0.458 \\
\hline \multirow{2}{*}{ Mediator variable } & $\begin{array}{l}\text { Non-agricultural } \\
\text { employment }\end{array}$ & $\begin{array}{l}\text { Number of non-agricultural employment/total } \\
\text { number of families (\%) }\end{array}$ & 0.358 & 0.360 \\
\hline & Agricultural output & $\begin{array}{l}\text { Agricultural output per unit area in } 2015 \\
(\mathrm{CNY} / \mathrm{mu})\end{array}$ & 1554.89 & $12,224.477$ \\
\hline \multirow[t]{11}{*}{ Control variables } & Age & Age of household head (year) & 54.830 & 11.524 \\
\hline & The square term of age & The square term of household head's age & 3139.107 & 1265.802 \\
\hline & $\begin{array}{l}\text { Education of household } \\
\text { head }\end{array}$ & $\begin{array}{l}1=\text { no school; } 2=\text { primary school; } 3=\text { junior high } \\
\text { school; } 4=\text { high school; } 5=\text { technical secondary } \\
\text { school; } 6=\text { junior college; } 7=\text { undergraduate } \\
\text { college; } 8=\text { master's degree; } 9=\text { Ph.D. }\end{array}$ & 2.515 & 0.957 \\
\hline & $\begin{array}{l}\text { Health status of } \\
\text { household head }\end{array}$ & $\begin{array}{l}1=\text { very healthy; } 2=\text { relatively health; } \\
3=\text { generally health; } 4=\text { relatively unhealthy; } \\
5=\text { very unhealthy }\end{array}$ & 2.837 & 0.988 \\
\hline & Political status & $\begin{array}{l}\text { If the head of the farmer household is a } \\
\text { Communist Party member }=1 \text {; otherwise }=0\end{array}$ & 0.102 & 0.303 \\
\hline & Female proportion & The proportion of females in households (\%) & 0.473 & 0.159 \\
\hline & Family status & Is the family poor? no $=0$, yes $=1$ & 0.154 & 0.361 \\
\hline & Dependency ratio & $\begin{array}{l}\text { The proportion of household members under the } \\
\text { age of } 16 \text { or over the age of } 64(\%)\end{array}$ & 0.273 & 0.265 \\
\hline & $\begin{array}{l}\text { Fixed investment in } \\
\text { agricultural production }\end{array}$ & $\begin{array}{l}\text { The total value of household agricultural } \\
\text { machinery. (CNY) }\end{array}$ & 2532.943 & $11,619.495$ \\
\hline & Cultivated land scale & Total cultivated farmland area $(\mathrm{mu})$ & 7.530 & 8.066 \\
\hline & Planting structure & $\begin{array}{l}\text { Output value of food crops/gross agricultural } \\
\text { output value (\%) }\end{array}$ & 0.498 & 0.485 \\
\hline
\end{tabular}

Dependent variable: Based on previous studies [20], the economic welfare of farmers' families is measured by the per capita annual income and the per capita consumption 
expenditure. It can be seen from Table 2 that the economic welfare of farmers' families with new agricultural business entities in this village is significantly higher than that of rural households without new agricultural business entities in the village, and it is significant at the $1 \%$ statistical level.

Table 2. Difference between groups of variables.

\begin{tabular}{lcc}
\hline \multicolumn{1}{c}{ Variables } & $\begin{array}{c}\text { Without New Agricultural } \\
\text { Business Entities in This } \\
\text { Village }\end{array}$ & $\begin{array}{c}\text { With New Agricultural } \\
\text { Business Entities in the } \\
\text { Village }\end{array}$ \\
\hline $\begin{array}{l}\text { Economic welfare of farmers' } \\
\text { family (the per capita } \\
\begin{array}{l}\text { consumption expenditure of } \\
\text { farmers' families) }\end{array}\end{array}$ & 8.420 & $8.5550^{* * *}$ \\
\hline $\begin{array}{l}\text { Economic welfare of farmers' } \\
\text { family (the per capita annual } \\
\text { income of farmers' families) }\end{array}$ & 8.560 & $8.8710^{* * *}$ \\
\hline $\begin{array}{l}\text { Mediator variable } \\
\text { (non-agricultural } \\
\text { employment) }\end{array}$ & 0.213 & $0.2250^{* *}$ \\
\hline $\begin{array}{l}\text { Mediator variable } \\
\text { (agricultural output) }\end{array}$ & 3.129 & $3.3010^{* *}$ \\
\hline
\end{tabular}

Note: in order to save space, only the differences between groups of dependent variables and mediator variables are listed. The data in the table is the mean values of each variable, ${ }^{* * *}$ and ${ }^{* *}$ are expressed at $1 \%$ and $5 \%$ significance levels, respectively.

Mediator variable: The mediator variables in this article include non-agricultural employment and agricultural output. It can be seen from Table 2 that the non-agricultural employment and agricultural output of households with new agricultural business entities in this village are significantly higher than those without new agricultural business entities in the village, and it is significantly positive at the $1 \%$ statistical level.

Control variable: Based on previous studies by Ruan [3] and Lu et al. [21], this article selects farmer personal characteristics, family characteristics, and agricultural production and operation characteristics. Among them, farmer personal characteristics include age, the square term of age, education, health status, and political status; family characteristics include family status, female proportion, and dependency ratio; agricultural production and operation characteristics include fixed investment in agricultural production, cultivated land scale, and the planting structure.

\subsection{The Benchmark Regression Model}

\subsubsection{Benchmark Regression Model}

In order to quantitatively estimate the effects of the new agricultural business entities on the economic welfare of farmers' families, the econometric model could be specified as follows:

$$
Y_{\mathrm{i}}=\alpha+\beta X_{\mathrm{i}}+\lambda C_{\mathrm{i}}+\varepsilon
$$

where $Y_{\mathrm{i}}$ is the observed value of the economic welfare of the $i$-th farmers' family and represented by the per capita annual income and the per capita annual consumption expenditure. $X_{\mathrm{i}}$ is the core independent variable, $C_{\mathrm{i}}$ is a vector of control variables, $\alpha, \beta$, and $\lambda$ are the parameters to be estimated, and $\varepsilon$ is the random disturbance term.

\subsubsection{Mediating Effect}

Following the mediation effect model developed by Wen [22], we used the following three models to test the mediating effect of non-agricultural employment and agricultural 
output on the relationship between new agricultural business entities and the economic welfare of farmers' families:

$$
\begin{gathered}
Y_{\mathrm{i}}=\mathrm{a}_{1}+\mathrm{a}_{2} E_{\mathrm{i}}+\mathrm{a}_{3} X_{\mathrm{i}}+\varepsilon_{1} \\
M_{\mathrm{i}}=\mathrm{b}_{1}+\mathrm{b}_{2} E_{\mathrm{i}}+\mathrm{b}_{3} X_{\mathrm{i}}+\varepsilon_{2} \\
Y_{\mathrm{i}}=\mathrm{c}_{1}+\mathrm{c}_{2} E_{\mathrm{i}}+\mathrm{c}_{3} M_{\mathrm{i}}+\mathrm{c}_{4} X_{\mathrm{i}}+\varepsilon_{3}
\end{gathered}
$$

where $Y_{\mathrm{i}}$ is the observed value of the economic welfare of the $\mathrm{i}$-th farmers' family, $E_{\mathrm{i}}$ represents the core independent variable, $X_{\mathrm{i}}$ represents a vector of control variables, the coefficient $a_{2}$ in Equation (2) represents the total effect of the new agricultural business entities on the economic welfare of the i-th farmer's family, the coefficient $b_{2}$ in Equation (2) represents the influence of new agricultural business entities on the mediation variables, $M_{\mathrm{i}}$ is the value of mediation variable of the $\mathrm{i}$-th farmer's family (including non-agricultural employment and agricultural output), $c_{2}$ and $c_{3}$ are the direct effects of new agricultural business entities and mediator variables on the economic welfare of the ith farmer's families, respectively; parameters $\varepsilon_{1}, \varepsilon_{2}, \varepsilon_{3}$ are the corresponding error terms. Bringing Formula (3) into Formula (4), the mediator effect of the new agricultural business entities can be obtained, i.e., $b_{2} \times c_{3}$ the new agricultural business entities have an indirect impact on the economic welfare of farmers' families through the mediating variables of agricultural employment and agricultural output.

\subsubsection{Propensity Score Matching}

In this paper, propensity score matching (PSM) was used to match the treatment group (with new agricultural business entities) and the control group (without new agricultural business entities). Controlling the consistency of external conditions, this paper discusses the impact of new agricultural business entities on the economic welfare of farmers' families. The research steps are as follows:

Step 1: Calculating the propensity score value. The personal characteristics of decision makers, family characteristics, and agricultural production and operation characteristics of the sample objects are selected as covariates, and Logit model is used to calculate whether the sample object has the tendency score of new agricultural business entities.

$$
P S_{\mathrm{i}}=P\left[D_{\mathrm{i}}=1 \mid X_{\mathrm{i}}\right]=E\left[D_{\mathrm{i}}=0 \mid X_{\mathrm{i}}\right]
$$

where $D_{\mathrm{i}}=1$ and $D_{\mathrm{i}}=0$ indicates that the new agricultural business entities exist and do not exist in the village respectively, and $X_{\mathrm{i}}$ represents observable farmer characteristics.

Step 2: Performing propensity score matching. In order to ensure the robustness of the matching results, this paper selects the following three mainstream matching methods: $\mathrm{K}$ nearest neighbor caliper matching, kernel matching, and nearest neighbor matching.

Step 3: Calculating the average processing effect. According to the counterfactual analysis framework, the average treatment effect (ATT) of the treatment group is calculated to reflect the impact of new agricultural business entities on the economic welfare of farmers' families, and its expression is:

$$
A T T=E\left(Y_{1 \mathrm{i}} \mid D_{\mathrm{i}}=1\right)-E\left(Y_{0 \mathrm{i}} \mid D_{\mathrm{i}}=1\right)
$$

where $Y_{1 \mathrm{i}}$ represents the economic welfare of farmers' families with new agricultural business entities in the village; $Y_{0 \mathrm{i}}$ represents the economic welfare of farmers' families without new agricultural business in the village; $E\left(Y_{1 \mathrm{i}} \mid D_{\mathrm{i}}=1\right)$ can be observed, while $E\left(Y_{0 \mathrm{i}} \mid D_{\mathrm{i}}=1\right)$ cannot be observed, and it is necessary to use propensity score matching to construct an alternative index of $E\left(Y_{0 \mathrm{i}} \mid D_{\mathrm{i}}=1\right)$. 


\section{Results Analysis}

\subsection{Benchmark Regression Results}

In this paper, the stata13 software is used to estimate the constructed benchmark regression model, and the impact of new agricultural business entities on the economic welfare of farmers' families are obtained (Table 3). Compared with the farmers without new agricultural business entities in the village, the per capita annual income and per capita annual consumption expenditure of farmers' families with new agricultural business entities increased by $26.5 \%(\exp (0.235)-1)$, and $9.09 \%(\exp (0.087)-1)$ respectively. Combined with the previous theoretical analysis, it shows that the new agricultural business entities can improve the economic welfare of farmers' families, and hypothesis 1 is established.

Table 3. The influence of new agricultural business entities on the economic welfare of farmers' families.

\begin{tabular}{|c|c|c|c|c|}
\hline & (1) & (2) & (3) & (4) \\
\hline & $\begin{array}{l}\text { The Per Capita } \\
\text { Annual Income of } \\
\text { Farmers' Families }\end{array}$ & $\begin{array}{l}\text { The Per Capita } \\
\text { Annual Income of } \\
\text { Farmers' Families }\end{array}$ & $\begin{array}{c}\text { The Per Capita } \\
\text { Annual Consumption } \\
\text { Expenditure of } \\
\text { Farmers' Families }\end{array}$ & $\begin{array}{c}\text { The Per Capita } \\
\text { Annual Consumption } \\
\text { Expenditure of } \\
\text { Farmers' Families }\end{array}$ \\
\hline \multirow[t]{2}{*}{$\begin{array}{l}\text { New agricultural } \\
\text { business entities }\end{array}$} & $0.306^{* * *}$ & $0.221 * * *$ & $0.104^{* * *}$ & $0.082 * * *$ \\
\hline & $(0.029)$ & $(0.027)$ & $(0.021)$ & $(0.020)$ \\
\hline \multicolumn{5}{|l|}{$\begin{array}{l}\text { Personal characteristics } \\
\text { of decision makers }\end{array}$} \\
\hline \multirow[t]{2}{*}{ Age of household head } & & $-0.027^{* * *}$ & & $-0.337^{* * *}$ \\
\hline & & $(0.009)$ & & $(0.006)$ \\
\hline \multirow[t]{2}{*}{ The square term of age } & & $0.000^{* * *}$ & & $0.000 * * *$ \\
\hline & & $(0.000)$ & & $(0.000)$ \\
\hline \multirow[t]{2}{*}{$\begin{array}{c}\text { Education of household } \\
\text { head }\end{array}$} & & $0.134^{* * *}$ & & $0.082^{* * *}$ \\
\hline & & $(0.014)$ & & $(0.011)$ \\
\hline \multirow[t]{2}{*}{$\begin{array}{l}\text { Health status of } \\
\text { household head }\end{array}$} & & $-0.123^{* * *}$ & & 0.001 \\
\hline & & $(0.013)$ & & $(0.010)$ \\
\hline \multirow[t]{2}{*}{ Political status } & & 0.093 ** & & $0.135 * * *$ \\
\hline & & $(0.042)$ & & $(0.032)$ \\
\hline \multicolumn{5}{|l|}{ Family characteristics } \\
\hline \multirow[t]{2}{*}{ Female proportion } & & $-0.287^{* * *}$ & & 0.029 \\
\hline & & $(0.079)$ & & $(0.059)$ \\
\hline \multirow[t]{2}{*}{ Family status } & & $-0.236^{* * *}$ & & $-0.064^{* *}$ \\
\hline & & $(0.035)$ & & $(0.026)$ \\
\hline \multirow[t]{2}{*}{ Dependency ratio } & & $-0.627^{* * *}$ & & $-0.312 * * *$ \\
\hline & & $(0.055)$ & & $(0.041)$ \\
\hline \multicolumn{5}{|l|}{$\begin{array}{l}\text { Agricultural } \\
\text { production and } \\
\text { Operation } \\
\text { characteristics }\end{array}$} \\
\hline \multirow[t]{2}{*}{$\begin{array}{l}\text { Fixed investment in } \\
\text { agricultural production }\end{array}$} & & $0.025^{* * *}$ & & $0.005 *$ \\
\hline & & $(0.003)$ & & $(0.003)$ \\
\hline
\end{tabular}


Table 3. Cont.

(1)

(2)

(3)

(4)

\begin{tabular}{|c|c|c|c|c|}
\hline & $\begin{array}{l}\text { The Per Capita } \\
\text { Annual Income of } \\
\text { Farmers' Families }\end{array}$ & $\begin{array}{l}\text { The Per Capita } \\
\text { Annual Income of } \\
\text { Farmers' Families }\end{array}$ & $\begin{array}{c}\text { The Per Capita } \\
\text { Annual Consumption } \\
\text { Expenditure of } \\
\text { Farmers' Families }\end{array}$ & $\begin{array}{c}\text { The Per Capita } \\
\text { Annual Consumption } \\
\text { Expenditure of } \\
\text { Farmers' Families }\end{array}$ \\
\hline \multirow[t]{2}{*}{ Cultivated land scale } & & $0.013^{* * *}$ & & -0.001 \\
\hline & & $(0.002)$ & & $(0.001)$ \\
\hline \multirow[t]{2}{*}{ Planting structure } & & $-0.396^{* * *}$ & & -0.017 \\
\hline & & $(0.026)$ & & $(0.019)$ \\
\hline \multirow[t]{2}{*}{ _cons } & $8.509 * * *$ & $9.559 * * *$ & $8.388^{* * *}$ & $9.425 * * *$ \\
\hline & $(0.024)$ & $(0.240)$ & $(0.017)$ & $(0.178)$ \\
\hline $\mathrm{N}$ & 7764 & 7764 & 7764 & 7764 \\
\hline $\mathrm{R}^{2}$ & 0.014 & 0.116 & 0.003 & 0.047 \\
\hline
\end{tabular}

Note: ${ }^{* * *}, * *$ and ${ }^{*}$ are expressed at 1,5 , and $10 \%$ significance levels, respectively. Robust standard errors are in parentheses.

As shown in Table 3, among the personal characteristics of farmer decision-making, the age of household head has positive significant impact on economic welfare of farmers' families, but the square of age of the household head is significantly negative, indicating that with the increase of the age of household head, the impact on the economic welfare of farmers' families is promoted firstly and then inhibited, i.e., the economic welfare of farmers' families has an inverted U-shaped change with age. The education level of decision makers has a significant positive impact on the economic welfare of farmers' families, indicating that farmers with higher educational attainment have higher per capita annual income and expanding consumption expenditure [23]. This means rural human capital accumulation is necessary for economic welfare of farmers' families in rural areas. The political status has a significant positive impact on the economic welfare of farmers' families. The reason may be that Communist Party members have more opportunities to come into contact with new things and new ideas, and have more ways to obtain income, so it is more conducive to improving the economic welfare level of farmers' families. In addition, Regression (2) shows that the health status of household head has a negative significant impact on the per capita annual income of farmers' families. This finding indicates that the per capita annual income of farmers' families decreased with the deterioration of the health status of householders. The main reason is that the low health level of household heads, to a certain extent, reduces the agricultural production efficiency of farmers and hinders farmers from working in cities, and thus reduces the per capita annual income.

Among the family characteristics, family status has a negative significant impact on the economic welfare of farmers' families, indicating that the poorer the rural households, the more unfavorable the conditions improve the economic welfare level of the farmers' families. The dependency ratio has a negative significant impact on the economic welfare of farmers' families. This can be attributed to the fact that the cost of children's education and care time are high, while the elderly's ability to participate in labor is weak (most elderly people cannot perform agricultural labor) and medical expenses are high. Therefore, the dependency ratio has an inhibitory effect on the economic welfare of farmers' families. In addition, the female proportion in the household has a negative significant impact on the per capita annual income of farmers' families; this result is consistent with Geng's [24]. This association is primarily due to two reasons: on the one hand, due to the influence of historical traditions and customs, the family model of "the man goes out to work while the women look after the house" is dominant in rural areas, women need to invest more time and energy in the family, and their participation in the labor market has stronger time constraints, thereby reducing the per capita annual income of farmers' families; on the 
other hand, male farmers' labor ability and going-out working opportunities are higher than women, so the income level is relatively high [25].

Among the characteristics of production and operation, fixed asset investment in agricultural production has a positive significant impact on the economic welfare of farmers' families. The main reason is that fixed investment in agricultural production can improve agricultural infrastructure and production conditions, expand farmland management area, improve production efficiency [26], increase agricultural income, and improve the economic welfare of farmers' families. The cultivated land scale has a positive significant impact on the per capita annual income of farmers' families. As a "rational economic man", the main reason for farmers to expand the scale of farmland management is to obtain considerable agricultural income. With other incomes unchanged, the increase of agricultural income will further improve the per capita annual income of farmers' families [20]. The planting structure has a negative impact on the per capita annual income of farmers' families. The main reason is that income from economic crops is higher than income from food crops. Under the double squeeze of high costs and low prices, the income of food crops is lower [27]. Therefore, planting economic crops is more conducive to increasing the economic income of farmers [28-31].

\subsection{Mediating Effect}

\subsubsection{The Mediating Effect Test of Non-Agricultural Employment}

According to the above model, this article first examines whether the new agricultural business entities affect the economic welfare of farmers' families through non-agricultural employment. It can be seen from Table 4 that the new agricultural business entities promote non-agricultural employment of farmers, indicating that the new agricultural business entities transfer a large number of farmers' land in the village to expand the scale of farmland management, which affects the resource allocation of farmers' families in the village. Under the combined effect of "urban force" and "rural force", farmers with non-agricultural advantages transfer agricultural labor to non-agricultural sectors. After adding the mediator variable of the non-agricultural employment, the influence of the non-agricultural employment on the per capita annual consumption expenditure of farmers' families and the per capita annual income of farmers' families is still significantly positive. Because the parameter estimates of $b_{2}, c_{1}$, and $c_{2}$ are significant, it indicates that the mediating effect of the non-agricultural employment exists, but it is a partial mediating effect. The mediation effect accounted for $3.15 \%$ and $13.78 \%$ of the total effect, respectively. Combined with the Bootstrap test, the mediating effect $b_{2} c_{3}$ of non-agricultural employment is significant. Bootstrap results show that the intermediary path of nonagricultural employment is significant at the statistical levels of $5 \%$ and $1 \%$ respectively for the per capita annual consumption expenditure and the per capita annual income of farmers' families. Thus, hypothesis 2 is verified.

Table 4. Non-agricultural employment plays an intermediary role in the impact of new agricultural business entities on the economic welfare of farmers' families.

\begin{tabular}{|c|c|c|c|}
\hline Variables & $\begin{array}{c}(5) \\
\text { Non-Agricultural } \\
\text { Employment }\end{array}$ & $\begin{array}{c}\text { (6) } \\
\text { The Per Capita Annual } \\
\text { Consumption Expenditure } \\
\text { of Farmers' Families }\end{array}$ & $\begin{array}{c}\text { (7) } \\
\text { The Per Capita Annual } \\
\text { Income of Farmers' Families }\end{array}$ \\
\hline $\begin{array}{c}\text { New agricultural business } \\
\text { entities }\end{array}$ & $0.014^{* * *}$ & $0.079^{* * *}$ & $0.190 * * *$ \\
\hline & $(0.005)$ & $(0.020)$ & $(0.025)$ \\
\hline Non-agricultural employment & - & $\begin{array}{l}0.180 * * * \\
(0.044)\end{array}$ & $\begin{array}{c}2.128^{* * *} \\
(0.025)\end{array}$ \\
\hline Control variables & Yes & Yes & Yes \\
\hline _cons & $\begin{array}{l}0.506^{* * *} \\
(0.046)\end{array}$ & $\begin{array}{l}9.334^{* * *} \\
(0.179)\end{array}$ & $\begin{array}{l}8.481^{* * *} \\
(0.220)\end{array}$ \\
\hline $\mathrm{N}$ & 7764 & 7764 & 7764 \\
\hline$R^{2}$ & 0.133 & 0.049 & 0.266 \\
\hline
\end{tabular}




\subsubsection{The Intermediary Effect Test of Agricultural Output}

Firstly, we test whether agricultural output variables play an intermediary role in the process where new agricultural business entities promote the economic welfare of farmers' families. It can be seen from Table 5 that the new agricultural business entities promote agricultural output. The main reason is that the new agricultural business entities reduce the opportunity cost of farmers, and increase agricultural output through knowledge spillover and technology spillover. After adding the mediator variable of the agricultural output, the impact of agricultural output on the per capita annual consumption expenditure and the per capita annual income of farmers' families is still significantly positive. Because the parameter estimates of $b_{2}, c_{1}$, and $c_{2}$ are significant, it indicates that the mediating effect of the agricultural output exists, but it is a partial mediating effect. The mediation effect accounted for $2.62 \%$ and $3.03 \%$ of the total effect, respectively. The Bootstrap test results also show that for the per capita consumption expenditure and the per capita annual income of farmers' families, the mediating path of agricultural output is significant at the statistical level of $5 \%$. Thus, hypothesis 3 is established.

Table 5. The intermediary role of agricultural output in the influence of new agricultural business entities on the economic welfare of farmers' families.

(9)

Variables
(8) Agricultural Output
The Per Capita Annual Consumption Expenditure of Farmers' Families
(10)

The Per Capita Annual Income of Farmers' Families

\begin{tabular}{|c|c|c|c|}
\hline $\begin{array}{c}\text { New agricultural business } \\
\text { entities }\end{array}$ & $0.156^{* *}$ & $0.080^{* * *}$ & $0.214^{* * *}$ \\
\hline & $(0.073)$ & $(0.020)$ & $(0.027)$ \\
\hline Agricultural output & - & $\begin{array}{l}0.014^{* * * *} \\
(0.003)\end{array}$ & $\begin{array}{c}0.043^{* * * *} \\
(0.004)\end{array}$ \\
\hline Control variables & Yes & Yes & Yes \\
\hline _cons & $\begin{array}{l}-0.189 * * * \\
(0.632)\end{array}$ & $\begin{array}{c}9.428^{* * *} \\
(0.178)\end{array}$ & $\begin{array}{c}9.567^{* * *} \\
(0.238)\end{array}$ \\
\hline $\mathrm{N}$ & 7764 & 7764 & 7764 \\
\hline $\mathrm{R}^{2}$ & 0.360 & 0.049 & 0.128 \\
\hline
\end{tabular}

Note: ${ }^{* *}$ and ${ }^{* *}$, are expressed at 1,5, and 10\% significance levels, respectively. Robust standard errors are in parentheses.

\subsection{Robustness Checks}

\subsubsection{The Test of Propensity Score Matching}

In the process of model construction in this paper, we may face endogenous problems. The core independent variable of the new agricultural business entities will have the problem of "self-selection". Generally speaking, the regions with faster economic development and higher level of economic welfare are more likely to attract new agricultural business entities to enter the countryside for agricultural investment [32]. At the same time, farmers with higher levels of economic welfare may optimize the allocation of family resources by transferring land, which attracts new agricultural business entities to enter the countryside. Therefore, the propensity score matching (PSM) method is used in this part. According to whether the new agricultural business entities exist in the village, it is divided into a treatment group (with new agricultural business entities) and a control group (without new agricultural business entities), and near similar observable variables can be found between the two groups for matching. Under the same other conditions, it is more scientific to test the causal relationship between variables by comparing the differences in economic welfare of farmers' families between the treatment group (with new agricultural business entities in the village) and the control group (without new agricultural business entities in the village). Table 6 reports the test results of kernel matching, and the standard errors of each variable after matching are less than $10 \%$. The $\mathrm{T}$ test results do not reject the original hypothesis that there is no systematic difference between the existence of new agricultural 
business entities and the non-existent of new agricultural business entities. These results indicate that propensity matching scores can effectively reduce the systematic differences between the two samples.

Table 6. Results of balance test.

\begin{tabular}{|c|c|c|c|c|c|c|c|}
\hline \multirow{2}{*}{ Variables } & \multirow{2}{*}{$\begin{array}{l}\text { Unmatched } \\
\text { (U)/Matched } \\
\text { (M) }\end{array}$} & \multicolumn{2}{|c|}{ Mean } & \multicolumn{2}{|c|}{$\%$ Reduction } & \multicolumn{2}{|c|}{$T$ Test } \\
\hline & & Treated & Control & $\%$ Bias & Bias & T-Statistics & $p$-Value \\
\hline \multirow{2}{*}{ Age of head of the household } & $\mathrm{U}$ & 54.57 & 55.437 & -7.5 & & -3.04 & 0.002 \\
\hline & M & 54.595 & 54.932 & -2.9 & 61.1 & -1.52 & 0.128 \\
\hline \multirow{2}{*}{ The square term of age } & $\mathrm{U}$ & 3109.9 & 3207.5 & -7.7 & & -3.11 & 0.002 \\
\hline & M & 3112.6 & 3151.4 & -3.1 & 60.2 & -1.60 & 0.109 \\
\hline \multirow{2}{*}{ Education of head of the household } & $\mathrm{U}$ & 2.547 & 2.440 & 11.2 & & 4.52 & 0.000 \\
\hline & M & 2.543 & 2.534 & 1.0 & 91.1 & 0.51 & 0.613 \\
\hline \multirow{2}{*}{ Physical condition } & $\mathrm{U}$ & 2.820 & 2.878 & -5.8 & & -2.36 & 0.018 \\
\hline & M & 2.820 & 2.834 & -1.4 & 76.0 & -0.73 & 0.464 \\
\hline \multirow{2}{*}{ Political status } & $\mathrm{U}$ & 0.098 & 0.112 & -4.6 & & -1.86 & 0.063 \\
\hline & M & 0.098 & 0.098 & -0.1 & 98.9 & -0.03 & 0.978 \\
\hline \multirow{2}{*}{ Proportion of women } & $\mathrm{U}$ & 0.474 & 0.472 & 1.3 & & 0.52 & 0.603 \\
\hline & M & 0.474 & 0.473 & 0.9 & 32.5 & 0.46 & 0.647 \\
\hline \multirow{2}{*}{ Family status } & $\mathrm{U}$ & 0.144 & 0.177 & -9.2 & & -3.76 & 0.000 \\
\hline & M & 0.144 & 0.150 & -1.6 & 83.7 & -0.81 & 0.420 \\
\hline \multirow{2}{*}{ Dependency ratio } & $\mathrm{U}$ & 0.267 & 0.286 & -7.2 & & -2.93 & 0.003 \\
\hline & M & 0.267 & 0.274 & -2.6 & 63.5 & -1.38 & 0.168 \\
\hline \multirow{2}{*}{$\begin{array}{l}\text { Fixed investment in agricultural } \\
\text { production }\end{array}$} & $\mathrm{U}$ & 2.804 & 2.209 & 15.8 & & 6.26 & 0.000 \\
\hline & M & 2.782 & 2.727 & 1.5 & 90.6 & 0.74 & 0.457 \\
\hline \multirow{2}{*}{ Cultivated land scale } & $\mathrm{U}$ & 7.976 & 6.486 & 19.7 & & 7.48 & 0.000 \\
\hline & M & 7.867 & 8.043 & -2.3 & 88.2 & -1.09 & 0.277 \\
\hline \multirow{2}{*}{ Planting structure } & $\mathrm{U}$ & 0.487 & 0.523 & -7.4 & & -2.96 & 0.003 \\
\hline & M & 0.488 & 0.485 & 0.6 & 91.4 & 0.33 & 0.743 \\
\hline
\end{tabular}

In this paper, $\mathrm{K}$ nearest neighbor caliper matching, kernel matching, and nearest neighbor matching are used to measure the average processing effect of new agricultural business entities on the economic welfare of farmers' families. The results are shown in Table 7. The ATT values calculated by the above three methods are relatively close, indicating that the analysis results are robust.

Table 7. The processing effect of propensity score matching.

\begin{tabular}{|c|c|c|c|c|c|c|}
\hline & Matching Algorithms & Treated & Controls & Difference & S.E. & T-Stat \\
\hline \multirow{3}{*}{$\begin{array}{l}\text { The per capita annual } \\
\text { consumption } \\
\text { expenditure of farmers' } \\
\text { families }\end{array}$} & $\begin{array}{c}\text { K nearest neighbor } \\
\text { caliper matching }(n=6)\end{array}$ & 8.491 & 8.400 & 0.091 & 0.023 & $3.93 * * *$ \\
\hline & Kernel matching & 8.491 & 8.404 & 0.087 & 0.022 & $3.89^{* * *}$ \\
\hline & $\begin{array}{l}\text { nearest neighbor } \\
\text { matching }(n=2)\end{array}$ & 8.491 & 8.394 & 0.096 & 0.025 & $3.93^{* * *}$ \\
\hline \multirow{3}{*}{$\begin{array}{l}\text { The per capita annual } \\
\text { income of farmers' } \\
\text { families }\end{array}$} & $\begin{array}{c}\text { K nearest neighbor } \\
\text { caliper matching }(n=6)\end{array}$ & 8.810 & 8.561 & 0.249 & 0.032 & $7.88^{* * *}$ \\
\hline & Kernel matching & 8.810 & 8.562 & 0.248 & 0.030 & $8.15^{* * *}$ \\
\hline & $\begin{array}{l}\text { nearest neighbor } \\
\text { matching }(n=2)\end{array}$ & 8.810 & 8.558 & 0.253 & 0.035 & $7.32 * * *$ \\
\hline
\end{tabular}

Note: ${ }^{* * *}$ represents at $1 \%$ significance levels.

\subsubsection{The Test of Replacing Core Independent Variables}

In order to make the results more convincing, this article adopts replacing the core independent variables, replacing "whether the new agricultural business entities exist in the village" with "the number of new agricultural business entities in the village". As can be seen from Table 8, after replacing the core independent variable, the number of new agricultural business entities in the village has a positive significant impact on the per 
capita annual income and the per capita annual consumption expenditure of the farmers' families at the $1 \%$ level, which is consistent with the previous results, indicating that the research results are relatively robust.

Table 8. Robustness test results of independent variable substitution method.

\begin{tabular}{|c|c|c|}
\hline Variables & $\begin{array}{c}\text { (11) } \\
\text { The Per Capita Annual Income of } \\
\text { Farmers' Families }\end{array}$ & $\begin{array}{l}(\mathbf{1 2}) \\
\text { The Per Capita Annual Consumption } \\
\text { Expenditure of Farmers' Families }\end{array}$ \\
\hline \multirow{2}{*}{$\begin{array}{l}\text { Number of new agricultural business } \\
\text { entities in the village (taking logarithm) }\end{array}$} & $0.083^{* * *}$ & $0.028^{* * *}$ \\
\hline & $(0.010)$ & $(0.007)$ \\
\hline Control variables & Yes & Yes \\
\hline \multirow[t]{2}{*}{ _cons } & $9.548^{* * *}$ & $9.427 * * *$ \\
\hline & $(0.239)$ & $(0.178)$ \\
\hline $\mathrm{N}$ & 7764 & 7764 \\
\hline $\mathrm{R}^{2}$ & 0.117 & 0.047 \\
\hline
\end{tabular}

Note: ${ }^{* * *}$ represents at $1 \%$ significance levels. Robust standard errors are in parentheses.

\section{Discussion and Conclusions}

Based on the data of the China Household Finance Survey (CHFS) in 2015, this paper constructs a theoretical model of the impact of new agricultural business entities on economic welfare of farmers' families. This paper analyzes the impact and its mechanism of new agricultural business entities on economic welfare of farmers' families by using benchmark regression and mediating effect model, and comes to the following conclusions: (1) The existence of new agricultural business entities in this village can significantly improve the economic welfare level of farmers' families. The specific performance is that the new agricultural business entities can increase the per capita annual income of farmers' families, and can also promote the per capita annual consumption expenditure of farmers' families, so as to improve the overall economic welfare of farmers' families. (2) The new agricultural economic entities promote the economic welfare level of local farmers by increasing non-agricultural employment and agricultural output. The mediating effect of non-agricultural employment in the impact of new agricultural business entities on the economic welfare of farmers' families accounted for 3.15\% and $13.45 \%$, respectively; the mediating effect of agricultural output in the impact of new agricultural business entities on the economic welfare of farmers' families accounted for $2.66 \%$ and $3.11 \%$, respectively. (3) Education, physical condition, political status, female proportion, family status, dependency ratio, fixed investment in agricultural production, cultivated land scale, and planting structure are important factors that affect the per capita annual income of farmers' families; education, political status, family status, and dependency ratio are the important factors that affect the per capita consumption expenditure of farmers' families.

In summary, the following enlightenment is obtained: First, we should support highquality new agricultural business entities and give full play to the role of new agricultural business entities as "leaders". In the process of agricultural production, it is necessary to give full play to the technology and knowledge-driven effect of new agricultural business entities on local agricultural output, and form a virtuous cycle pattern of complementary advantages, resource sharing, and mutual benefit between small farmers and new agricultural business entities. Second, while vigorously developing and supporting the extension of the industrial chain of new agricultural business entities, it is necessary to establish and improve the non-agricultural employment information market and strengthen employment skills training for farmers. Ensuring that farmers who want to go out can obtain non-agricultural employment opportunities and effectively promoting the flow of rural labor force are the key links to promote the urban-rural integration development. Third, according to the research conclusions, considering the influence of education level, family status, and dependency ratio on the economic welfare level of farmers' families the local 
government should develop rural industries, promote the equalization of basic services in urban and rural areas, optimize rural residents' policies, reduce the burden on rural households, and improve the economic welfare level of farmers' families.

Our study can be extended in several directions: first, this study is a cross-sectional data set. When analyzing the effect of the new agricultural business entities on economic welfare of farmers' families, continuous multi-period panel data are better, so a follow-up survey will be conducted with the farmers to assess the dynamic change process of the influence of the new agricultural business entities on farmers. Secondly, the key variables studied in this paper are only measured by "whether the new agricultural business entities exist in the village". The characteristics and heterogeneity of different new agricultural business entities are not deeply analyzed, such as the scale and grade of different new agricultural business entities.

Author Contributions: L.C. and W.Z. conceived and designed the study, and L.C. completed the paper in English and revised it critically for important intellectual content; K.D. gave good research advice and revised the manuscript. All authors have read and agreed to the published version of the manuscript.

Funding: This research was funded by the National Social Science Fund of China (18AGL014).

Informed Consent Statement: Informed consent was obtained from all farmers involved in the study.

Data Availability Statement: The research data in this article can be obtained from survey and research Center for China household finance.

Acknowledgments: We would like to thank the editor and the anonymous reviewers for their helpful suggestions and comments.

Conflicts of Interest: The authors declare no conflict of interest.

\section{References}

1. Gao, M.; Xi, Y.; Wu, B. Analsis on the operating performance and differences of new agricultural operation entities-based on the survey data from fixed observation points in rural areas. J. Huazhong Agric. Univ. 2018, 5, 10-16+160-161. (In Chinese)

2. Guo, L.; Liu, Y. Agricultural commercialization process and function of family farms-comparison of different agricultural management operators. J. Northwest. AF Univ. 2015, 15, 87-91+128. (In Chinese)

3. Ruan, R.; Cao, B.; Zhou, P.; Zhen, F. The driving capacity of new agricultural management entities and its determinants: An analysis based on data from 2615 new agricultural management entities in China. Chin. Rural Econ. 2017, 11, 17-32. (In Chinese)

4. Song, H.; Shi, B.; Wu, B. The new agricultural business entities: Basic characteristics, financing needs and policy implications. Rural Econ. 2020, 10, 73-80. (In Chinese)

5. Wang, Q.; Guo, Q. Research on financing demand of new agricultural business entities-Based on the analysis of questionnaire in Sichuan Province. Financ. Econ. 2017, 8, 118-132. (In Chinese)

6. Wang, J.; Xiao, Q.; Li, J. Financing predicament and countermeasure of new agricultural proprietors. Issues Agric. Econ. 2018, 2, 71-77. (In Chinese)

7. Zhong, Z. China new agricultural operators since the reform and opening up: Growth, evolution and tread. J. Renmin Univ. China 2018, 32, 43-55. (In Chinese)

8. Zhang, L.; Feng, S.; Lu, H.; Qu, F. The impacts of farmland lease to tenants of different types on lessor household income: Evidence from JiangSu province. China Rural Surv. 2017, 5, 116-129. (In Chinese)

9. Tian, P. From farming to operating land: Change of farmland management model in process of urbanization. J. Huazhong Agric. Univ. 2017, 2, 103-108+134-135. (In Chinese)

10. Wang, L.; Kou, G.; Wang, S. Thoughts on constructing the benefit afflicting mechanism of new types of agribusiness and small household farmers. J. China Agric. Univ. Soc. Sci. 2019, 36, 89-97. (In Chinese)

11. $\mathrm{Xu}, \mathrm{X}$; $\mathrm{Wu}, \mathrm{B}$. Are cooperatives an ideal carrier for the organic connection between the production of small farmers and the development of modern agriculture? Chin. Rural Econ. 2018, 11, 80-95. (In Chinese)

12. Zhong, Z.; Wang, Y. The impacts of farmland scale and contract characteristics on the enthusiasm of new agricultural operator towards farmland consolidation: Based on the survey of 15 counties from 5 province. China Land Sci. 2019, 33, 89-98. (In Chinese)

13. Xie, J.; Yang, G.; Xu, Y.; Wang, G. influence mechanism and empirical analysis of rural land consolidation on the income and welfare of rural household. J. Agrotech. Econ. 2020, 12, 38-54. (In Chinese)

14. Li, N.; Wang, X.; Lu, H. The dual role and its dynamic transformation of agricultural machinery service of the new agricultural business entities: A preliminary analysis framework. Issues Agric. Econ. 2021, 2, 38-53. (In Chinese) 
15. Zhong, Z.; Tu, S.; Zhang, Z. The construction of close interest linking mechanism in agricultural industrialization. Reform 2021, 4, 107-120. (In Chinese)

16. Zhao, B.; Zhong, Y. Research on the behavioral mechanism of contract form selection between agricultural companies and farmers: Multi-case analysis based on aquatic vegetable industry. Issues Agric. Econ. 2020, 12, 74-86. (In Chinese)

17. Li, Y.; Xiong, C.; Yin, Z. Embedded cultivation of new agricultural operation subject and its driving function-Taking ShiCheng as an example. J. Northwest. AF Univ. 2020, 20, 143-152. (In Chinese)

18. Shao, S.; Li, Q.; Li, D. Capital to the rural areas: Entry mode choice and the corresponding influencing factors. J. Huazhong Agric. Univ. 2018, 5, 59-66+163. (In Chinese)

19. Han, X.; Liu, W.; Gao, Z. Selection preference and preference heterogeneity of smallholders' participation in agricultural industrial Chain: An analysis based on the choice experiment method. China Rural. Surv. 2020, 2, 81-99. (In Chinese)

20. Li, Z.; Zhuang, J. impact of land trusteeship on the economic welfare of farmers' families-The intermediation effect based on non-agricultural employment and agricultural output. J. Agrotech. Econ. 2021, 1, 20-31. (In Chinese)

21. Lu, Z. The welfare effects from the development of the new agricultural management entities. J. Quant. Tech. Econ. 2016, 33, 41-58. (In Chinese)

22. Wen, Z.; Ye, B. Analyse of mediating effects: The development of methods and models. Adv. Psychol. Sci. 2014, 22, 731-745. (In Chinese) [CrossRef]

23. Qi, H.; Liu, Y. Change of population age structure and the upgrading of household consumption: An empirical research based on CHPS data. China Population. Resour. Environ. 2020, 30, 174-184. (In Chinese)

24. Geng, P. Effect of land rights stability on farmers' income: Based on the perspective of factor configuration. J. Agro-For. Econ. Manag. 2020, 19, 611-623. (In Chinese)

25. He, X.; Kong, M. Financial Literacy, financial behavior and farmer's income: Based on survey date of farmers in Shaanxi province. J. Beijing Technol. Bus. Univ. 2019, 34, 1-11. (In Chinese)

26. Zhu, M.; Zhang, Q.; Cheng, G. The impact of agricultural fixed asset investment on global grain production increase: Performance differences of different income groups. J. Hunan Agric. Univ. 2021, 22, 23-31. (In Chinese)

27. Wu, S.; Yu, H.; Chu, Y. Limitations and breakthroughs in the study of "Non Grain" in cultivated land under agricultural scale management. J. Northwest. AF Univ. 2019, 19, 142-151. (In Chinese)

28. Cuong, N.V. Measuring the impact of cash crops on household expenditure and poverty in rural Viet Nam. Asia-Pac. Dev. J. 2009, $16,87-112$.

29. Masanjala, W.H. Cash crop liberalization and poverty alleviation in Africa: Evidence from Malawi. Agric. Econ. 2010, 35, 231-240. [CrossRef]

30. Corral, P.; Radchenko, N.; Winters, P. Heterogeneity of commercialization gains in the rural economy. Agric. Econ. 2018, 49, 131-143.

31. Papaioannou, K.J.; Haas, M.D. Weather Shocks and Agricultural Commercialization in Colonial Tropical Africa: Did Cash Crops Alleviate Social Distress? World Dev. 2017, 94, 346-365. [CrossRef]

32. Jiang, G.; Hu, H. Will industrial and commercial capitals investing in agriculture lead to "non-grain" use of farmers' land? Empirical evidence from the CLDS data. Financ. Trade Res. 2021, 32, 41-51. 